IRA-International Journal of Management \& Social Sciences

ISSN 2455-2267; Vol.05, Issue 01 (2016)

Pg. no. 122-130

Institute of Research Advances

http://research-advances.org/index.php/RAJMSS

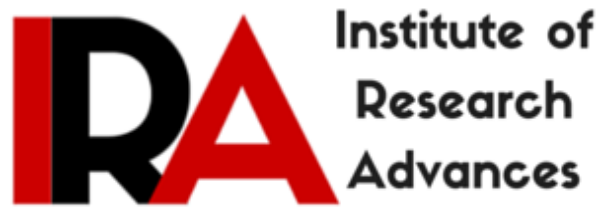

\title{
A Study Mutual Fund Investors Behavior in Kerala
}

\author{
${ }^{1}$ Sanesh. C \\ Assistant Professor \\ Sri Vyasa NSS College, Wadakkanchery \\ Thrissur, Kerala, India. \\ ${ }^{2}$ Greeshma. V \\ Guest Lecturer \\ Government College \\ Malappuram, Kerala, India.
}

Type of Review: Peer Reviewed.

DOI: http://dx.doi.org/10.21013/jmss.v5.n1.p13

\section{How to cite this paper:}

C, Sanesh, \& V, Greeshma (2016). A Study Mutual Fund Investors Behavior in Kerala. IRA-International Journal of Management \& Social Sciences (ISSN 24552267), 5(1), 122-130. doi:http://dx.doi.org/10.21013/jmss.v5.n1.p13

(C) Institute of Research Advances

\section{(cc) EY-NO}

This work is licensed under a Creative Commons Attribution-Non Commercial 4.0 International License subject to proper citation to the publication source of the work.

Disclaimer: The scholarly papers as reviewed and published by the Institute of Research Advances (IRA) are the views and opinions of their respective authors and are not the views or opinions of the IRA. The IRA disclaims of any harm or loss caused due to the published content to any party. 


ABSTRACT
A mutual fund is a special type of institution, a trust or an investment company which acts as an
investment intermediary and invests the savings of large number of people to the corporate securities
in such a way that investors get steady returns, capital appreciation and a low risk. This article focus
on investors behaviour towards mutual fund schemes is done at a general base. These expectations
of investors are influenced by their perception and humans generally relate perception to action.
Investor's behaviour may change from period to period even if the other variables influencing the
behaviour are held constant. The individual investors' decision making often relies on observable
socio-demographic variables to proxy for inherent psychological processes that drive investment
choices.

Keywords: Net asset value, Folio, Capitalisation

\section{INTRODUCTION}

In the present financial market, mutual funds have emerged as the key player of saving and investment process. Majority of the individual investors have been showing keen interest in the structured financial operation. With the growing emphasis on the adoption of well structural professional management of investments, the role of mutual fund has assumed greater importance..A mutual fund is the most suitable investment for the retail investors as it offers an opportunity to invest in a diversified, professionally managed portfolio at a relatively low cost. At the retail level, investors are unique and are a highly heterogeneous group. A large number of investment options are available to investors. Currently there are large numbers of schemes available and the Asset Management Companies (AMCs) compete against one another by launching new products or repositioning old ones. Unless mutual fund schemes are tailored to the changing needs, and the AMCs understand the fund selection behaviour of the investors; survival of funds will be difficult in future. This article focuses investors behaviour towards mutual fund schemes is on a general base.

\section{Statement of the problem}

Mutual funds have opened new vistas to millions of small investors by virtually taking investment to their doorstep. In India, a small investor generally goes for bank deposits, which do not provide hedge against inflation and often have negative real returns. Here the investor has limited access to price sensitive information and if available, may not be able to comprehend publicly available information couched in technical and legal jargons. Mutual funds have come, as a much needed help to these investors. MFs are looked upon by individual investors as financial intermediaries/ portfolio managers who process information, identify investment opportunities, formulate investment strategies, invest funds and monitor progress at a very low cost. Thus, the success of MFs is essentially the result of the combined efforts of competent fund managers and alert investors. A competent fund manager should analyse investor behaviour and understand their needs and expectations, to gear up the performance to meet investor requirements. In an atmosphere of constantly changing economic conditions, investors should keep up with the rapid changes and pursue the most popular trends in order to have their fingers on the pulse. Changing conditions encourage them to come up with new alternatives to their investment instruments. These alternatives consist of a mixture of numerous investment vehicles which are mainly formed by various types of mutual funds. It should be noted that the expectations of investors play a vital role in the financial markets. They influence the price of the securities, the volume traded and various other financial operations in actual practice. These expectations of investors are influenced by their perception and humans generally relate perception to action. Investor's behaviour may change from period to period even if the other variables influencing the behaviour are held constant. The individual investors' decision making often 
relies on observable socio-demographic variables to proxy for inherent psychological processes that drive investment choices.

The latent heterogeneity amongst investors in terms of their preferences and beliefs, form the underlying drivers of their behaviour. To gain a better understanding of the relations among individual investors' decision-making, the processes leading to these decisions and investment performance are taken in to consideration. Hence, with this background, the present study attempts to analyse the investment behaviour of Mutual Fund investors.

\section{Significance of the study}

Mutual fund is become an important part of the financial industry. Therefore it gives opportunity to an ordinary individual to invest in different companies with small amount of money. So it in necessitate to study the importance of the mutual fund in the public and how they are reached to the mutual fund etc.It is widely believed that Mutual Fund is a retail product designed to target small investors, salaried people and others who are intimidated by the stock market but, nevertheless, like to reap the benefits of stock market investing. It is evident that mutual funds have at the top of the agenda over the last decade thus, constituted the majority of many organisations' portfolios.

\section{Scope of the study}

The present study aims at tracking investors' preferences and priorities towards different type of mutual fund products and for identifying key features of a mutual fund for deciphering sustainable marketing variables in the design of a new mutual fund product. Besides the factors identified, the study provide key information inputs regarding investors' fund selection behaviour and post-buying behaviour that will guide future mutual fund product managers in designing attractive mutual fund products for the Indian market

\section{Objectives of the study}

1. To investigate the investment objectives of mutual fund investors across their time horizon, and demographic features.

2. To identify the saving and investment avenue preferences of mutual fund investors, and their level of preferences towards mutual fund products with respect to the time horizon, risk perception, and socio-economic characteristics.

3. To ascertain the key features of mutual fund products influencing the fund selection behaviour of mutual fund investors.

4. To assess the fund preferences of mutual fund investors in relation to their investment objectives, time horizon and risk perception.

5. To examine the post-buying behaviour of mutual fund investors in relation to their time horizon, risk perception and demographic profile.

6. To assess the product performance satisfaction level of the investors across the different types of mutual fund products.

\section{Research Methodology}

The present study adopted descriptive as well as an empirical research methodology based on the survey method. Here, the researcher makes use of an inductive research approach to construct the model based on the analysis. 


\section{Data Base}

The data required for the study have been collected from both primary and secondary sources. The study basically depends on the primary data collected from 90 sample mutual fund retail (individual) investors in Kerala through a structured questionnaire. In addition to this, the discussion with officials of AMCs, stock broking firms, agents and distributors of MF products, and experts in this field were conducted to collect required information. The survey was conducted during the period of 2016 June to 2016 august. The secondary data required for the study have been collected from the reports and publications of AMFI, SEBI, and RBI; books, journals, and periodicals; dissertations; and various websites; related with the subject.

\section{Instruments Used for the collection of primary data}

In order to collect the primary data required for the study, a structured questionnaire has been developed by the researcher. The questionnaire consists of three parts. First part comprises of questions related to demographic features and saving/investment avenue preferences of MF investors. The second part of the instrument deals with questions for assessing the pre-buying behaviour, and the last part consists of questions related to postbuying behaviour of MF investors

\section{Sampling Design:}

The universe of the study consists of as all those individual investors (retail investors) of mutual fund products whose names appearing in the portfolio records of different Asset Management Companies (AMCs) as on 30-5-2016.

\section{Sampling methodology}

Simple random sampling is used for the selection of samples for the study. 90 samples collected from all over the kerala are used for the study.

\section{Tools used for the study}

Suitable mathematical and statistical tools will be applied for analyzing the data and establishing certain vital relationships among important variables. Statistical Package for Social Sciences (SPSS version 20) is used to analyze the data.

\section{Limitations for the study}

1. The universe of the study is limited to the mutual fund investors in Kerala. In India majority of mutual fund investors are concentrated in metropolitan cities.

2. This study has not been conducted over an extended period of time having both ups and downs of stock market conditions which might have significant influence on investors buying behavior and preferences.

3. Few of mutual fund investors in kerala have shown reluctance in providing reliable financial data pertaining to certain items.

Analysis and interpretation

Table showing ranking of mutual fund investors objectives

\begin{tabular}{|l|l|l|l|}
\hline No. & Objective & Rating percentage & rank \\
\hline 1 & Return & 25.39 & 1 \\
\hline 2 & Liquidity & 17.46 & 3 \\
\hline 3 & Safety & 23.80 & 2 \\
\hline 4 & Tax Benefit & 11.11 & 5 \\
\hline 5 & Capital Appreciation & 14.28 & 4 \\
\hline
\end{tabular}




\begin{tabular}{|l|l|l|l|}
\hline 6 & Provision for contingencies & 7.93 & 6 \\
\hline
\end{tabular}

Source: Primary Data

we can infer that primary objective of mutual fund selection is the return offered by the scheme then safety, liquidity, and last will be the provision for contingencies.

\section{Mutual Fund Choices by Investors}

\begin{tabular}{|c|c|c|c|c|c|}
\hline Fund type & Selected & \%of selected & $\begin{array}{l}\text { Not } \\
\text { selected }\end{array}$ & $\begin{array}{l}\% \text { of } \\
\text { not } \\
\text { selected }\end{array}$ & Total \\
\hline Open ended fund & 72 & $80 \%$ & 18 & $20 \%$ & 90 \\
\hline Close ended fund & 15 & $17 \%$ & 75 & $83 \%$ & 90 \\
\hline Equity mutual fund & 78 & $87 \%$ & 12 & $13 \%$ & 90 \\
\hline Debt mutual fund & 38 & $42 \%$ & 52 & $58 \%$ & 90 \\
\hline Balanced mutual fund & 47 & $52 \%$ & 43 & $48 \%$ & 90 \\
\hline Tax saver mutual fund & 22 & $25 \%$ & 68 & $75 \%$ & 90 \\
\hline Money Market Fund & 7 & $8 \%$ & 83 & $92 \%$ & 90 \\
\hline Sectoral mutual fund & 14 & $16 \%$ & 76 & $84 \%$ & 90 \\
\hline Index fund & 9 & $10 \%$ & 81 & $90 \%$ & 90 \\
\hline Exchange Traded Fund & 14 & $16 \%$ & 76 & $84 \%$ & 90 \\
\hline Fund of fund & 4 & $4 \%$ & 86 & $96 \%$ & 90 \\
\hline Capital protection fund & 6 & $7 \%$ & 84 & $93 \%$ & 90 \\
\hline
\end{tabular}

Source: Primary Data

From table we can infer following things

1. Open ended funds got higher share of investments by investors, that is $80 \%$ of investors had exposure of open ended mutual funds.

2. Close ended mutual funds not attracted much investor fancy, ie $83 \%$ of investors not selected close ended funds.

3. Equity mutual funds are invested by most of the investors

4. Debt and balanced mutual fund got average investor attraction.

5. Tax saver mutual funds or ELSS schemes, money market mutual funds, sectoral mutual funds, Index mutual funds, ETF, Fund of fund and capital protection funds not awaken the interest of investors

\section{Rate of Influence Of Investors Mutual Fund Selection By Different Attributes}

\begin{tabular}{|l|l|l|l|l|l|l|}
\hline Source & $\begin{array}{l}\text { Least } \\
\text { influenced }\end{array}$ & $\begin{array}{l}\text { Less } \\
\text { influenced }\end{array}$ & influenced & $\begin{array}{l}\text { More } \\
\text { influenced }\end{array}$ & $\begin{array}{l}\text { Most } \\
\text { influenced }\end{array}$ \\
\hline 1 & Reference Groups(Friends/Relatives) & 8 & 11 & 24 & 22 & 15 \\
\hline 2 & News papers \&Magazines & 2 & 4 & 20 & 22 & 42 \\
\hline 3 & Brokers/Agents/ Financial Advisors & 12 & 13 & 12 & 18 & 35 \\
\hline 4 & Electronic Media(TV/Radio) & 5 & 8 & 22 & 30 & 25 \\
\hline 5 & Internet/Website/Email/Telephone/SMS & 1 & 3 & 25 & 27 & 34 \\
\hline
\end{tabular}




\begin{tabular}{|l|l|l|l|l|l|l|}
\hline 6 & Self Evaluation & 12 & 14 & 27 & 30 & 7 \\
\hline 7 & Financial Literacy Programs & 12 & 10 & 25 & 20 & 23 \\
\hline 8 & AMC's Influence & 7 & 25 & 30 & 16 & 16 \\
\hline 9 & Prospectus/Brochures/News Letters & 12 & 28 & 22 & 14 & 14 \\
\hline 10 & Hoardings \&Banners & 45 & 20 & 10 & 8 & 7 \\
\hline
\end{tabular}

\section{INTERPRETATION}

1. Friends and relatives are influencing in a big way of mutual fund selection

2. Newspapers and magazines publishing fund reports are mostly influencing investors

3. Brokers and agents are with the use of marketing tactics attracted investors attention fairly.

4. Investors are watching TV programmes related with capital market and mutual funds are more influencing them.

5. Investors are searching internet /fund house website and mutual fund analysts website before investing

6. Whatever be the source of information investors are deciding their investing fund after their self evaluation

7. Financial literacy programmes sponsored by SEBI and different fund houses attracted them for mutual fund investing

8. Mutual fund Asset Management companies are also impacting investors fund selection

9. Newsletters, hoardings, banners and brochures are not creating much impact in investment decision.

Rating of product attributes (features) while considering for selection of mutual fund schemes

\begin{tabular}{|l|l|l|l|l|l|l|}
\hline & Source & $\begin{array}{l}\text { Least } \\
\text { considered }\end{array}$ & $\begin{array}{l}\text { Less } \\
\text { considered }\end{array}$ & considered & $\begin{array}{l}\text { More } \\
\text { considered }\end{array}$ & $\begin{array}{l}\text { Most } \\
\text { considered }\end{array}$ \\
\hline 1 & Past Fund performance Record & 2 & 4 & 9 & 12 & 63 \\
\hline 2 & Funds reputation or brand name & 3 & 2 & 19 & 54 & 12 \\
\hline 3 & Schemes expense ratio & 24 & 12 & 20 & 21 & 13 \\
\hline 4 & Schemes portfolio/constituents & 1 & 4 & 19 & 39 & 27 \\
\hline 5 & Withdrawal facilities/redemption features & 3 & 5 & 28 & 30 & 24 \\
\hline 6 & Favourable rating by a rating agency & 2 & 2 & 4 & 20 & 62 \\
\hline 7 & Innovativeness of the scheme & 24 & 27 & 20 & 8 & 11 \\
\hline 8 & Loan facility & 38 & 34 & 10 & 6 & 2 \\
\hline 9 & Option to Switch scheme & 20 & 26 & 27 & 12 & 5 \\
\hline 10 & Annual return/Dividend & 4 & 5 & 4 & 30 & 47 \\
\hline 11 & Professional financial advisor & 8 & 8 & 25 & 32 & 17 \\
\hline 12 & Service standard & 9 & 12 & 20 & 27 & 22 \\
\hline
\end{tabular}

Source: Primary Data 


\section{Interpretation}

From the above table it is clear that

1. Investors are mostly considered past fund performance record ,ie here with $63 \%$

2. Funds reputation and brand name are also mostly considered by investors.

3. Scheme expense ratio is also a considering point by investors

4. Scheme portfolio is more considered by investors.

5. Easy availability of redemption money is highly considered by investors

6. Rating agencies star/number rating is highly influencing factor while investing a fund

7. Scheme innovativeness, loan facility and option to switch does not create much impact among investors.

8. Annual return are closely scrutinizing by investors for deciding holding of a particular mutual fund

9. Professional financial advisor and their service standard are also considered by investors before investing in a particular fund

Awareness level/financial literacy about the technical aspects of the mutual fund products.

\begin{tabular}{|l|l|l|l|l|l|l|}
\hline & Source & $\begin{array}{l}\text { Least } \\
\text { awareness }\end{array}$ & $\begin{array}{l}\text { Less } \\
\text { awareness }\end{array}$ & awareness & $\begin{array}{l}\text { More } \\
\text { awareness }\end{array}$ & $\begin{array}{l}\text { Most } \\
\text { awareness }\end{array}$ \\
\hline 1 & Market Risk & 8 & 6 & 19 & 28 & 29 \\
\hline 2 & Scheme Information Document & 31 & 28 & 20 & 12 & 9 \\
\hline 3 & AMC & 9 & 11 & 14 & 32 & 24 \\
\hline 4 & NAV (NetAssetValue) & 0 & 3 & 6 & 5 & 76 \\
\hline 5 & Open-end/close-endFund & 1 & 4 & 24 & 42 & 19 \\
\hline 6 & Types of fund/Scheme & 18 & 16 & 5 & 36 & 15 \\
\hline 7 & New Fund Offer(NFO)/SIP) & 4 & 2 & 4 & 32 & 58 \\
\hline 8 & Performance of portfolio & 15 & 16 & 8 & 32 & 19 \\
\hline 9 & Entry Load/ ExitLoad & 12 & 19 & 50 & 7 & 2 \\
\hline
\end{tabular}

Source: Primary Data

\section{Interpretation}

Above table shows the awareness level of mutual fund investors on different terminologies used in mutual fund shows that most of the terminologies used in mutual funds have better understanding among investors except scheme information document. Regarding scheme information document most of them are not looking the scheme information document before investing. 
Level of satisfaction about the performance of mutual fund products invested

\begin{tabular}{|l|l|l|l|l|l|l|}
\hline & Qualities & Very poor & poor & satisfactory & good & excellent \\
\hline 1 & Return/Dividend/Capital Appreciation & 6 & 14 & 30 & 22 & 18 \\
\hline 2 & $\begin{array}{l}\text { Transparency/Communication of up to date } \\
\text { market information }\end{array}$ & 20 & 38 & 16 & 14 & 2 \\
\hline 3 & Safety of Investment & 18 & 22 & 25 & 20 & 5 \\
\hline 4 & Service Quality & 4 & 9 & 31 & 26 & 20 \\
\hline 5 & Professional Mgt: & 1 & 8 & 25 & 28 & 28 \\
\hline 6 & Liquidity & 10 & 17 & 12 & 24 & 27 \\
\hline 7 & Overall performance & 4 & 7 & 14 & 25 & 30 \\
\hline
\end{tabular}

Source: Primary Data

Interpretation

Above table shows the satisfaction level of mutual fund investors after investing mutual fund shows that

1. Most of the investors are satisfied with the return after investing mutual fund scheme

2. Investors have opinion that mutual fund schemes are not much transperant regarding their disclosure.

3. Mutual fund is a moderately safe investment as per the opinion of investors

4. Fund houses are providing better service quality, professional management, liquidity and overall showing a better performance.

\section{Conclusion}

Mutual fund in an emerging market has become highly competitive which necessitates that MF marketers must fully understand the buying behaviour to be able to effectively market their mutual fund schemes. Mutual fund investment is considered as one of the investment avenues preferred by the investors. Longterm investors are showing more preferences towards mutual fund products. The investment objectives and investor's level of preferences towards mutual fund products vary with their time horizon of investment. It is evident that return and safety of investment are the prime objectives of the investors.

\section{Bibliography}

1. Anila, Mathews. (2009). Mutual Fund Distribution in India: A study on current trends and its impact on the Industry. In Guruswamy \& Ranganatham (Eds.), Global Financial System in the post crisis era-Challenges and opportunities, (644-652), Chennai: Vijay Nicols imprints ltd.

2. James, P. M. (2009).An evaluation of the asset management companies and their efficiency in portfolio management. M G University, Kottayam, Kerala.

3. Nilamadhav, Samal. (2009), The Factors Affecting investors preference for mutual funds in India, retrieved from http://www.ripublication.com /gjfm.htm

4. Alex, Clarke., Grant, Cullen., \& Dominic, Gasbarro. (2007). Mutual Fund Trades: Asymmetric Liquidity Preferences and Fund Performance. Journal of Financial Research, XXX, (4), 515-532.

5. Sushant, Nagpal. (2007). Psychology of investments and investor's preferences. Guru Jambeshwar University, Rohtak. 
6. Sandra, West., \& Victoria, Leonard. (2006). Understanding Investor Preferences for Mutual Fund Information. Investment Company Institute, Sandra West, United States, Retrieved from http:www.ici.org.

7. Anand, S., \& Murugaiah, V. (n.d). Analysis of components of investment performance - an empirical study of mutual funds in India, retrieved from, http://ssrn.com/abstract=961999.

8. Flotakis, Philippas, N. (2004). Chasing trend and losing money: open-end mutual fund investors' trading behaviour in Greece. Applied Economics Letters, 11, 117-121.

9. Thomas, Basil John,(2014) Mutual fund investors behaviour in Kerala, ph.d thesis submitted to Mahatma Gandhi University, Kerala 